Demir, T. T. (2021). Türkçe eğitimi alanında nicel araştırma yöntemleri kullanılarak yapılan doktora tezlerindeki eğilimler. Ana Dili Eğitimi Dergisi, 9(2), 543-560.

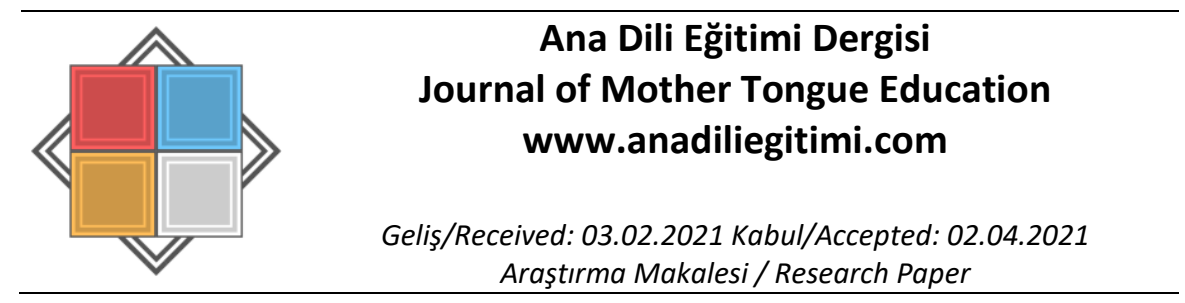

\title{
Türkçe Eğitimi Alanında Nicel Araştırma Yöntemleri Kullanılarak Yapılan Doktora Tezlerindeki Eğilimler
}

\author{
Talat Tarık DEMiR*
}

Öz

Bu çalışmada Türkçe eğitimi alanında 2010-2020 yılları arasında nicel araştırma yöntemleri kullanılarak hazırlanan doktora tezlerindeki eğilimleri belirlemek amaçlanmıştır. Doktora tezlerinden alana özgün katkılarda bulunması beklenir. Bu sebeple doktora tezlerinin incelendiği çalışmalar alandaki gelişimi ortaya koyacaktır. Yapılan çalışmada doktora tezleri incelenirken bilimsel araştırma yöntemleri açısından bir çerçeve çizilerek inceleme yapılmıştır. Çalışmada tarama modeli kullanıımıştır. Araştırma kapsamında incelenen tezlere Yükseköğretim Kurulu Ulusal Tez Merkezi aracılığıyla ulaşılmıştır. Bu kapsamda 323 teze ulaşılmış bunların 78 tanesinin nicel araştırma yöntemleriyle hazırlandığı tespit edilmiştir. Bu tezler hazırlanan tez sınıflama formu yardımıyla değerlendirilerek içerik analizi gerçekleştirilmiştir. Çalışma sonucunda nicel araştırma yöntemleriyle hazırlanan tezlerde dil becerileri merkezli konulara ağılık verildiği, deneysel desenlerle üretilen tezlerin oranının daha yüksek olduğu görülmüştür. Ortaokul öğrencileri üzerinde yapılan çalışmaların çoğunlukta olduğu tespit edilmiştir. Tezlerde en çok parametrik testlerle veri analizi yapılmıştır. Lisansüstü tezler üzerine farklı araştırma yöntemleri çerçevesinde araştırmalar yapılabilir.

Anahtar Kelimeler: Türkçe eğitimi, Doktora tezi, Nicel araştırma yöntemleri

\section{Trends in Doctoral Dissertations Made Using Quantitative Research Methods in Turkish Education}

\begin{abstract}
In this study, it was aimed to determine the trends in doctoral dissertations prepared using quantitative research methods in the field of Turkish education between 2010-2020. While examining the doctoral dissertations in the study, a framework was drawn in terms of scientific research methods. Survey model was used in the study. The theses examined within the scope of the research were reached through the Higher Education Council National Thesis Center. In this context, 323 theses were reached and 78 of them were found to be prepared by quantitative research methods. Content analysis was carried out by evaluating these theses with the help of the thesis classification form. As a result of the study, it was observed that in theses prepared with quantitative research methods, language skills centered subjects were emphasized and the rate of theses produced with experimental designs was higher. It has been determined that studies conducted on secondary school students are in the majority. In theses, mostly data analysis has been done with parametric tests. Research can be done on postgraduate theses within the framework of different research methods.
\end{abstract}

Keywords: Turkish education, Doctoral thesis, Quantitative research methods

\footnotetext{
*Arş. Gör., Necmettin Erbakan Üniversitesi, Ereğli Eğitim Fakültesi, Türkçe ve Sosyal Bilimler Eğitimi Bölümü, Konya, talatdemir28@gmail.com, ORCID: orcid.org/0000-0003-2037-4088
} 


\section{Giriş}

Türkçe eğitimi alanında bilimsel anlamda önemli bir boyutta üretim yapılmaktadır. Lisansüstü programların artmasıyla alandaki tez üretimi de hızlanmıştır. Lisansüstü tezlerle özgün konulara eğilerek derin ve kapsamlı bilgi üretilmesi amaçlanır. Türkçe eğitimi alanında yapılan lisansüstü tezlerin özellikle doktora tezlerinin analizi alandaki gereksinimleri görmek açısından değere sahiptir. Üretilen tezlerin nitelik anlamında bir incelemeye tabi tutulması alanda yapılacak bilimsel araştırmalar açısından yol gösterici olacaktır.

Bilimsel araştırma, fiziksel ve sosyal olgular üzerine bilimsel bilgiyi ortaya çıkarmak üzere planlı ve sistemli olarak yürütülen etkinlikleri kapsar. Bilimsel araştırmalar kontrollüdür, tümdengelim ve tümevarım içerir. Elde edilen görüş ve düşüncelerin test edilmesi yani deneye dayandırılması gerekir. Araştırma sonuçlarının ise bilim adamlarınca tartışılarak doğruluğunun kabul edilmesi ya da edilmemesi gerekir (Demirbaş, 2014).

Bilimsel araştırmalarda gerçeği veya doğruyu bulmak için sistematik süreçlerle veri toplanır, düzenlenir, çözümlenerek anlamlandırılır. Sürecin sonucunda elde edilen sonuçlar belli bir formatta paylaşılır. Bu sistematik süreçler bilimsel araştırma yöntemleriyle ilerler, şekillenir (Can, 2019).

Alanyazın tarandığında bilimsel araştırmaların sınıflandırılmasında farklı ölçütlerin esas alındığı görülür. Temel alınan felsefeye göre araştırmalar nicel ve nitel araştırmalar olarak ikiye ayrılır. Nicel araştırmalarda gerçeklik araştırmacıdan bağımsız görülür ve bu gerçeklik nesnel bir şekilde gözlenebilir, ölçülebilir, analiz edilebilir. Nicel araştırmada araştırmacının nedensellik ilişkilerini açıklama, tahminde bulunma ve genelleme yapma gibi amaçları vardır. Araştırmacı nicel verileri toplar, analizini yapar ve değişkenler arasındaki ilişkileri kanıtlamak için çalışır. Nitel araştırmalar ise gerçekliğin bulunduğu bağlamda araştırmacının deneyim ve bilgileriyle anlamlandırılmasını esas alan yorumcu bakış açısına işaret eder (Büyüköztürk, Çakmak, Akgün, Karadeniz ve Demirel, 2016). Bu iki bilimsel araştırma yöntemi dışında karma yöntem araştırması da vardır. Karma yöntem araştırmalarında araştırma problemi çok boyutlu ve kapsamlı olarak incelenir. Pragmatist felsefe ışığında nicel ve nitel yöntemler beraber kullanılarak araştırma gerçekleştirilir (Yıldırım ve Şimşek, 2016).

Araştırma sürecinde elde edilen bilginin sayısal değerler olarak ifade edilmesi ve ölçülebilmesi nicel araştırmalarda temel çalışma ilkesidir. Nicel araştırmalar hipotezlere dayandırılmalı ve bu hipotezler test edilmelidir (Ekiz, 2020). Nicel araştırmalarda araştırma stratejileri pospozitivist dünya görüşünden etkilenmiştir. Postpozitivizm sebeplerin ürün veya sonuçları belirlediğini savunan nedenselci felsefi görüştür. Nicel araştırmalarda nesnel yaklaşımlar ve istatistiksel işlemler kullanılır. Nicel araştırmalarda desenleri deneysel ve deneysel olmayan desenler şeklinde sınıflandırmak mümkündür (Creswell, 2017). Büyüköztürk vd. (2016) ise nicel araştırmalarda desenleri tarama araştırmaları, korelasyonel araştırmalar, nedensel karşılaştırma araştırmaları, deneysel araştırmalar, tasarım ve geliştirme araştırması, meta-analiz araştırmaları şeklinde başılıklandırmıştır.

Lisansüstü tezler bilimsel araştırmalar içerisinde çok önemli bir yere sahiptir. Lisansüstü tezlerde bir probleme bilimsel yöntemler kullanarak çözümler üretmek, tartışılan düşüncelere netlik kazandırmak ve daha önce üzerinde çalışma yapılmamış bir konuda ayrıntılı bilgiler elde etmek amaçlanır. Yüksek lisans ve doktora tezleri olarak lisansüstü tezleri sınıflandırmak mümkündür.

Yüksek lisans tezleriyle araştırmacıdan araştırma yöntem ve tekniklerini, alana dair terminolijiyi ve bilimsel dili kullanabilme becerilerini kazanması beklenir. Bu çalışmalar akademik dünyayı keşif amacı taşıyan ilk basamaklar olduğundan doktora çalışmalarına nazaran daha az bilimsel ilgiyi çekmektedir (Özçakmak, 2017). Doktora tezlerinde araştırmacıdan beklenen alanda özgün çalışmalar yapmasıdır. Yapılan çalışmayla bilime orijinal katkılarda bulunulması gerekir. Akademik hayat doktora tezleri temel alınarak gelişme gösterir. Araştırmacı açısından branşlaşma doktora teziyle başlar. Bu açıdan doktora tezi akademik hayatta en önemli basamak olarak görülür (Boyacı ve Demirkol, 2018).

Türkçenin eğitimi alanında ülkemizde daha özel ve branşlaşmaya dönük çalışmalar 1990'।ı yıllarda görülmeye başlanmıştır. Türkçenin Eğitimi-Öğretimi Ana Bilim Dalı 1989-1990 tarihinde Gazi Üniversitesi Sosyal Bilimler Enstitüsü'ne bağlı olarak lisansüstü programları yürütmek üzere kurulmuştur (Güzel, 2003). Türkçe eğitimi alanı 1990'lı yıllarda yapılanma sürecine girmiş bilimsel 
üretim bakımından literatüre ciddi katkılarda bulunmuştur. Alanda yapılan bilimsel çalışmalar derin bir bilimsel birikimin oluşmasını sağlamış yanı sıra araştırma yeterliliği olarak uluslararası boyutta araştırmalar gerçekleşmiştir (Şeref ve Karagöz, 2019).

Bilimsel alanlarda yapılan çalışmaların artmasıyla bilginin üretimi de hızlanmaktadır. Artan bilgiyle araştırmacının kısa zamanda hedeflediği bilgiye ulaşması zorlaşmaktadır. Bu sebeple belli bir alanda yapılan çalışmaların çerçevelerini çizen analiz çalışmaları önem arz etmektedir. Bu üst çalışmalar bilimsel disiplinlerdeki birikimin derlenerek değerlendirilmesine imkân sağlar, ilgili alanın derinliği hakkında bilgi verir, genel görünüm üzerine kanaat oluşturur. Bu anlamda Türkçe eğitimi alanına bakıldığında bu alan üzerine sürekli olarak akademik çalışmalar yapılmakta ve çalışmalar nicelik anlamında artmaktadır (Temizkan ve Erdevir, 2020). Dolayısıyla Türkçe eğitimi alanında yapılan araştırmaların analiz edildiği çalışmaların da önemi artmaktadır. Türkçe eğitimi alanında yapılacak analiz çalışmalarıyla alandaki eksikler net olarak görülebilecek, çalışmalar yapılırken farklı açılardan yaklaşımlar sergilenebilecektir. Alandaki araştırmacılar için bu tür çalışmalar ışık olacaktır. Araştırmacılar hangi konuların nasıl ve kimler tarafından çalışıldığını görecek o alandaki bilimsel birikimin farkında olacaktır.

Alanyazın tarandığında Türkçe eğitiminde yapılan lisansüstü tezlerin incelendiği çalışmaların olduğu görülmektedir. Deniz ve Karagöl (2016) yaptığı çalışmada eğitim bilimleri alanında yapılan lisansüstü tezlerin başlıklarını söz dizimi ve kelime sayısı bakımından incelemeye tabi tutmuştur. Karagöl (2018) bir başka çalışmasında akademik yazma açısından lisansüstü tezlerin durumunu tespit etmeyi amaçlamıştır. Sevim ve Özdemir Eren (2012) çalışmalarında Türkçe eğitimi alanıyla ilgili hazırlanan yüksek lisans tezlerinin özetlerine ve başlıklarına eleştirel bir yorum sunmayı amaçlamışlardır. Yağmur Şahin, Kana ve Varışoğlu (2013) yaptıkları çalışmada 2000-2011 yılları arasında yapılan Türkçe eğitimi alanındaki tezlerin örneklem, yöntem, veri toplama araçları ve veri analizi yöntemi gibi özellikler bakımından eğilimlerini tespit etmeye çalışmıştır. Doğan ve Özçakmak (2014) dinleme eğitimi üzerine hazırlanan lisansüstü tezleri incelemiş ve bir meta-analiz çalışması yapmıştır. Kan (2014) yaptığı doktora teziyle 2006-2011 yılları arasında Türkçe eğitimi alanında yapılan uygulamalı/betimsel nitelikteki yüksek lisans tezlerinin giriş, yöntem, bulgular, tartışma ve sonuç bölümlerindeki sözbilimsel hareketlerin dilsel görünüm ve sıralamalarını belirlemeyi amaçlamıştır. Özçakmak (2017) Türkçe eğitimi alanında yapılan lisansütü tezlerde konu yönelimlerini tespit etmeye çalışmışır. Tezleri üniversite, enstitü, hedef kitle, yıl, konu bakımından sınıflandırmaya tabi tutmuştur. Eyüp (2020) Türkçe öğretmenleriyle ilgili hazırlanan lisansüstü tezler üzerine bir içerik analizi yapmıştır. Çalışmada Türkçe öğretmenleri üzerine yapılan tezlerin eğilimlerini belirlemek amaçlanmıştır. Şahin, Çiftçi ve Başbayrak (2020) Türkçe eğitimi alanında 2000-2018 yılları arasında teknoloji kullanımına dönük hazırlanmış tezlerdeki eğilimleri tespit etmeyi amaçlamıştır. Direkçi, Akbulut ve Şimşek (2020) yaptıkları çalışmada değerler eğitiminin konu edinildiği Türkçe eğitimi lisansüstü tezlerindeki eğilimleri irdelemeye çalışmışlardır. Temizkan ve Erdevir (2020) ise Türkçe eğitimi alanında yazılı anlatımla ilgili hazırlanmış tezleri incelemiştir. Çalışma yapılırken tezlerde kullanılan değişkenler farklı açılardan değerlendirilmeye çalışımıştır. Ayrıca alan yazın tarandığında Türkçe eğitimi alanında dört temel dil becerileri üzerine yazılmış lisansüstü tezlerin incelendiği çalışmaların (Cin Şeker,2020; Tok ve Potur,2015; Özdemir,2018) yapıldığı da tespit edilmiştir.

Türkçe eğitimi alanında lisansüstü tezlerin incelendiği çalışmalar araştırıldığında sadece doktora düzeyinde yapılan tezlerin incelendiği çalışmaların olduğu da görülmektedir. Boyacı ve Demirkol (2018) tarafından yapılan çalışmada Türkçe eğitiminde yapılan doktora tezlerinin başlık, konu, künye ve özet bakımından akademik alana katkıları değerlendirilmeye çalışılmıştır. Turan, Sevim ve Tunagür (2018) alanda hazırlanan doktora tezlerinin özet kısımlarına dair bir içerik analizi yapmışlardır. Özet kısmında yer verilmesi gereken bilgilere bu kısımlarda ne kadar yer verildiğine dair tespitlerde bulunmuşlardır. Gülen Canlı ve Tepeli (2019) alanda dil bilgisi öğretimi üzerine yapılan doktora tezlerinin sistematik incelemesini yapmaya çalışmıştır. Çalışmada dil bilgisi öğretimine dair hazırlanan doktora tezleri bilim dalları, enstitü, yıl, kullanılan yöntem ve teknikler, çalışma grupları, sonuç ve öneriler açısından incelenmiştir.

Yüksek lisans ve doktora tezlerinin birlikte değerlendirildiği çalışmalarda kısmen yüzeysel bilgiler verildiği görülmektedir. Sadece doktora tezlerinin incelendiği çalışmalarda ise bilimsel 
araştırma yöntemleri açısından bir çerçeve çizilerek duruma yaklaşılmadığı tespit edilmiştir. Bu çalışmada Türkçe eğitimi alanında nicel araştırma yöntemleri kullanılarak 2010-2020 yılları arasında yazılan doktora tezleri incelenmiştir.

Bu çalışmada nicel araştırma yöntemleriyle hazırlanan tezler seçilerek bilimsel araştırma yöntemleri açısından bir çerçeve çizilmeye çalışılmıştır. Nicel araştırma yöntemleri temel alınarak tezlere bu araştırma yöntemlerinin özellikleri açısından bir yaklaşım sergilenmeye çalışımıştır. Her araştırma yönteminin kendine has özellikleri ve yaklaşımları vardır. Nicel araştırma yöntemleri kullanılarak yapılan tezler incelenerek bu tezlerdeki farklı, ortak ve benzer yönler ortaya koyulmaya, tezlerde göze çarpan özellikler tespit edilmeye çalışılacaktır. Bu durum daha nitelikli çıkarımların yapılmasına katkı sağlayacak, alandaki çalışmaların incelenmesini kolaylaştıracaktır. Meta-analiz çalışmaları için ipuçları sunacaktır. Alandaki çalışmaların özgünlüğü ve bilimsel yöntemlerin kullanılma durumları hakkında çıkarımlar yapılabilecektir. Çalışmanın nicel araştırma yöntemleri kullanılarak hazırlanan doktora tezleriyle sınırlandırıımış olması araştırmacılara daha net ve detaylı bilgiler verecektir. Alanda yapılan doktora çalışmalarındaki yönelimlere dair daha özel ve derin bilgiler edinilmesi mümkün olacaktır. Araştırma alanı özelleştikçe o alanda daha derin bilgiler üretilebilecektir. Bu çalışma Türkçe eğitimi alanında nicel araştırma yöntemleri kullanılarak hazırlanan doktora tezlerini analiz ederek doktora seviyesindeki nicel araştırmaların eğilimlerini ve doktora tezleri içinde nicel yöntemlerle hazırlanan tezlerinin durumunu ortaya koyması bakımından önemlidir. Bu bağlamda alanı yakından tanımak isteyen araştırmacılara yol gösterici nitelikte bir çalışma olduğu düşünülmektedir.

Yapılan bu çalışmayla 2010-2020 yılları arasında Türkçe eğitimi alanında nicel araştırma yöntemleri kullanılarak hazırlanan doktora tezlerinin çeşitli özellikler açısından incelenerek eğilimlerin tespit edilmesi amaçlanmıştır. Bu amaca bağlı olarak aşağıdaki araştırma sorularına cevaplar aranmıştır.

Türkçe eğitimi alanında nicel araştırma yöntemleri kullanılarak hazırlanan doktora tezlerinde;

1- Yıllara ve diğer araştırma yöntemleriyle hazırlanan doktora tezlerine göre dağılım oranı nasıldır?

2- Konu dağılımı nasıldır?

3-Yöntemsel özellikler (araştırma deseni, veri toplama araçları, veri analiz yöntemleri, örneklem seçim yöntemi ve örneklem büyüklüğü) bakımından dağılım nasıldır?

4- Seçilen hedef kitle bakımından dağılım nasıldır?

5- Hedef kitlenin örneklem/çalışma grubunun büyüklüğüne göre dağııımı nasıldır?

6- Desenlerin örneklem büyüklüğüne ve hedef kitleye göre dağılımı nasıldır?

\section{Araştırmanın Modeli}

\section{Yöntem}

Bu çalışmada tarama modeli kullanılmıştır. Tarama modeliyle geçmişte ya da hâlen var olan bir durumun olduğu gibi betimlenmesi amaçlanır. Çalışma konusu olan nesne, birey ya da olay kendi koşulları içinde var olduğu gibi tanımlanmaya çalışılır. Tarama araştırmacısı yazılı belge, istatistikler, görüntü ve ses kayıtları, resimler gibi çeşitli kayıtlara başvurarak elde edeceği verileri bir sistem içinde bütünleştirerek yorumlayabilir (Karasar, 2020).

\section{Örneklem}

Çalışmanın dokümanlarını 2010-2020 yılları arasında nicel araştırma yöntemleri kullanılarak hazırlanan Türkçe eğitimi alanındaki doktora tezleri oluşturmaktadır. Çalışma Ulusal Tez Merkezi'nde dizinlenen erişime açık tezlerle sınırlandırılmıştır. Bu araştırma sonucunda 323 doktora tezine ulaşılmış, bu tezlerden 78 tanesinin sadece nicel araştırma yöntemleri kullanılarak üretildiği tespit edilmiştir. Çalışma sırasında nitel ve nicel yöntemlerin birlikte kullanıldığı ancak karma yöntem olarak ifade edilmeyen tezler karma yöntemle hazırlanan tezler içerisinde değerlendirilmiştir. Nicel araştırma yöntemleri kullanılarak hazırlanan 78 tez bu çalışmanın çalışma dokümanlarını oluşturmaktadır. 


\section{Veri Toplama Araçları}

Veriler toplanırken araştırmacı tarafından oluşturulan tez sınıflama formu kullanılmıştır. Form ekte sunulmuştur. Bu formda tez adı, yayın yılı, konu, araştırma deseni, hedef kitle, örneklem türü, veri toplama araçları, veri analiz yöntemleri ve örneklem büyüklüğü başlıkları bulunmaktadır

\section{Verilerin Toplanması}

Çalışmada incelenen tezlere Yükseköğretim Kurulu Ulusal Tez Merkezi aracılığıyla ulaşılmıştır. Çalışma için tez merkezinde ana bilim dalı ve bilim dalı taramaları yapılmıştır. Türkçe Eğitimi Bilim Dalı, Türkçe Öğretmenliği Bilim Dalı, Türkçenin Eğitimi ve Öğretimi Bilim Dalı ile Türkçe Eğitimi Ana Bilim Dalı, Türkçe Öğretimi Ana Bilim Dalı, Türkçe Öğretmenliği Ana Bilim Dalı ve Türkçenin Eğitimi ve Öğretimi Ana Bilim Dalı başlıkları altında tarama yapılmıştır. Taramalar sonucunda tespit edilen tezler, tez sınıflama formunda yer alan dokuz farklı kategoride araştırmacı tarafından kodlanmıştır. Araştırmacı dışında bir araştırmacı daha tespit edilen tezleri aynı formu kullanarak kodlamış, farklılıklar tespit edildiğinde bir uzmandan da görüş alınarak uzlaşmaya varılmıştır. Bu şekilde güvenilirlik sağlanmıştır.

\section{Verilerin Analizi}

Tez sınıflama formuyla elde edilen verilerin analizi içerik analizi esas alınarak yapılmıştır. İçerik analizi belli kurallara dayanan kodlamalarla bir mesajın belli özelliklerinin sistematik ve objektif olarak tanınmasına dönük çıkarımların yapıldığı bir tekniktir. İçerik analiziyle sözlü ve yazılı materyaller sistemli bir şekilde analiz edilir ve kurallara uygun kodlamalarla sayısallaştırılır. Birbirine benzeyen veriler belli temalar içinde bir araya getirilip okuyucunun anlayabileceği şekilde yorumlanır (Yıldırım ve Şimşek, 2016). Bu çalışmada içerik analizi yapılırken tezler tez adı, yayın yılı, konu, araştırma deseni, hedef kitle, örneklem türü, veri toplama araçları, veri analiz yöntemleri ve örneklem büyüklüğü olmak üzere dokuz kategori altında sınıflandırılmıştır. Kodlamalarla elde edilen verilerden temalara ulaşılmıştır. Veriler analiz edilirken betimsel istatistik türlerinden olan yüzde ve frekans hesaplamaları yapılmıştır. Sonuçlar tablolar aracılığıyla gösterilerek yorumlanmıştır.

\section{Geçerlik ve Güvenirlik}

Araştırmada güvenirliği sağlamak için araştırmacı tarafından hazırlanan form üç uzman tarafından incelenmiştir. Çalışmada veri toplama aracı olarak kullanılan tez sınıflama formunun güvenirliği Miles ve Huberman (2016) formülü ile hesaplanarak tespit edilmiştir. Bu işlem sonucunda uyuşum oranı 0.93 olarak hesaplanmıştır. Bu sonuç formun güvenilir olduğunu göstermektedir. Bu formda tez adı, yayın yılı, konu, araştırma deseni, hedef kitle, örneklem türü, veri toplama araçları, veri analiz yöntemleri ve örneklem büyüklüğü başlıkları bulunmaktadır. Tezler incelenip bu forma işlendikten sonra veri analizi yapılmıştır. Bu dokuz kategori altında tezler analiz edilip yorumlanmıştır.

\section{Araştırma ve Yayın Etiği}

Bu çalışmada "Yükseköğretim Kurumları Bilimsel Araştırma ve Yayın Etiği Yönergesi" kapsamında uyulması belirtilen tüm kurallara uyulmuştur. Yönergenin ikinci bölümü olan "Bilimsel Araştırma ve Yayın Etiğine Aykırı Eylemler" başlığı altında belirtilen eylemlerden hiçbiri gerçekleştirilmemiştir.

\section{Bulgular}

Bu bölümde araştırma sorularından yola çıkılarak Türkçe eğitimi alanında 2010-2020 yılları arasında nicel yöntemler kullanılarak hazırlanan doktora tezlerinin analiz edilmesiyle elde edilen bulgulara yer verilmiştir. 
Nicel Tezlerin Yıllara ve Diğer Araştırma Yöntemleriyle Hazırlanan Doktora Tezlerine Göre Dağılımı

Nicel araştırma yöntemleriyle hazırlanan doktora tezlerinin yıllara ve diğer araştırma yöntemleriyle hazırlanan doktora tezlerine göre dağılımına dair elde edilen bulgular Tablo 1'de gösterilmiş

Tablo 1.

Nicel Tezlerin Yıllara ve Diğer Araştırma Yöntemleriyle Hazırlanan Tezlere Göre Dağılımları

\begin{tabular}{lcccccccc} 
& Nicel & \multicolumn{3}{c}{ Nitel } & \multicolumn{3}{c}{ Karma } & \multicolumn{3}{c}{ Toplam } & $\%$ \\
\hline Yıllar & $\mathrm{f}$ & $\%$ & $\mathrm{f}$ & $\%$ & $\mathrm{f}$ & $\%$ & $\mathrm{f}$ & $\%$ \\
\hline 2010 & 9 & 2.78 & 12 & 3.71 & - & - & 21 & 6.50 \\
\hline 2011 & 12 & 3.71 & 4 & 1.23 & 2 & 0.61 & 18 & 5.57 \\
\hline 2012 & 5 & 1.54 & 9 & 2.78 & 1 & 0.30 & 15 & 4.64 \\
\hline 2013 & 9 & 2.78 & 5 & 1.54 & 2 & 0.61 & 16 & 4.95 \\
\hline 2014 & 6 & 1.85 & 15 & 4.64 & 10 & 3.09 & 31 & 9.59 \\
\hline 2015 & 6 & 1.85 & 14 & 4.33 & 20 & 6.19 & 40 & 12.38 \\
\hline 2016 & 5 & 1.54 & 9 & 2.78 & 10 & 3.09 & 24 & 7.43 \\
\hline 2017 & 5 & 1.54 & 20 & 6.19 & 15 & 4.64 & 40 & 12.38 \\
\hline 2018 & 8 & 2.47 & 14 & 4.33 & 14 & 4.33 & 36 & 11.14 \\
\hline 2019 & 9 & 2.78 & 15 & 4.64 & 25 & 7.73 & 49 & 15.17 \\
\hline 2020 & 4 & 1.23 & 11 & 3.40 & 18 & 5.57 & 33 & 10.21 \\
\hline Toplam & 78 & 24.07 & 128 & 39.57 & 117 & 36.16 & 323 & 100 \\
\hline
\end{tabular}

Tablo 1 incelendiğinde Türkçe eğitimi alanında 2010-2020 yılları arasında toplam 323 doktora tezinin hazırlandığı görülmektedir. Bu tezlerin 78'ini (\%24.07) nicel araştırma yöntemleri kullanılarak hazırlanan tezleri oluşturmaktadır. Tezlerin $128^{\prime}$ i nitel, 117 'sinin ise karma yöntemlerle hazırlandığı görülmektedir. Nicel araştırma yöntemleriyle hazırlanan tezlerin daha az olduğu anlaşılmaktadır. En az 2020 yılında, en çok 2011 yılında nicel araştırma yöntemleriyle doktora tezleri hazırlanmıştır. Tabloya bakıldığında son yıllarda karma yöntemlerin kullanılma oranının arttığı görülmektedir.

Tezlerdeki Konu Dağılımı

Tablo 2'de tezler konularına göre sınıflandırılmış, dağııım oranları belirtilmiştir.

Tablo 2.

Tezlerin Konulara Göre Dağııımı

\begin{tabular}{lcc}
\hline Tez Konusu & $f$ & $\%$ \\
\hline Yaklaşım, yöntem veya modelin okuma becerisine etkisi & 8 & 10.25 \\
\hline Yaklaşım, yöntem veya modelin yazma becerisine etkisi & 6 & 7.69 \\
\hline Duyuşsal özelliklerle dil becerisi ilişkisi & 6 & 7.69 \\
\hline Yaklaşım, yöntem veya modelin dinleme becerisine etkisi & 5 & 6.41 \\
\hline Edebi türün dil eğitimine etkisi & 5 & 6.41 \\
\hline Yaklaşım, yöntem veya modelin konuşma becerisine etkisi & 4 & 5.12 \\
\hline Bilgisayar destekli eğitimin ana dili eğitimine etkisi & 4 & 5.12 \\
\hline Yapılandırılmış eğitim ortamının dil becerilerine etkisi & 4 & 5.12 \\
\hline Yaklaşım, yöntem veya modelin dil becerilerine etkisi & 3 & 3.84 \\
\hline Dil bilgisi öğretiminde yaklaşım, yöntem veya modelin etkisi & 3 & 3.84 \\
\hline Yaklaşım, yöntem veya modelin duyuşsal özelliklere ve başarıya etkisi & 3 & 3.84 \\
\hline Türk soylu öğrencilerde Türkçe eğitimi ve duyuşsal özellikler & 3 & 3.84 \\
\hline Yabancılara Türkçe öğretiminde duyuşsal özelliklerle dil becerisi ilişkisi & 2 & 2.56 \\
\hline Dil becerileri arasındaki ilişki & 2 & 2.56 \\
\hline Öğretim programının dil eğitimindeki etkisi & 2 & 2.56 \\
\hline
\end{tabular}




\begin{tabular}{lcc}
\hline Eğitsel oyunların dil becerilerinin gelişimine etkisi & 2 & 2.56 \\
\hline Kelime bilgisi dil becerisi ilişkisi & 2 & 2.56 \\
\hline Yabancılara Türkçe öğretiminde öğretmen yeterlilikleri & 1 & 1.28 \\
\hline Okuma becerisi ve diğer disiplinlerdeki başarı ilişkisi & 1 & 1.28 \\
\hline İşitme engellilerde dil eğitimi & 1 & 1.28 \\
\hline Yazma etkinliklerine yönelik algılar & 1 & 1.28 \\
\hline Yabancılara Türkçe öğretiminde bilgisayar destekli eğitimin başarıya etkisi & 1 & 1.28 \\
\hline Yurt dışındaki Türk çocuklarında dil becerileri & 1 & 1.28 \\
\hline Yurt dışındaki Türklerde dil farkındalığı & 1 & 1.28 \\
\hline Yaklaşım, yöntem veya modelin kelime öğrenimine etkisi & 1 & 1.28 \\
\hline Bibliyoterapinin duyuşsal ve bilişsel özelliklere etkisi & 1 & 1.28 \\
\hline Yazma becerisi değerlendirmesi & 1 & 1.28 \\
\hline Yabancılara Türkçe öğretiminde ek öğretiminin dil gelişimine etkisi & 1 & 1.28 \\
\hline Yabancılara Türkçe öğretiminde dinleme metinlerinin anlaşılırlığı & 1 & 1.28 \\
\hline Iki dillilik temelinde incelemeler & 1 & 1.28 \\
\hline Yabancılara Türkçe öğretiminde dil öğretim sürecinin değerlendirmesi & 1 & 1.28 \\
\hline
\end{tabular}

Tablo 2'ye bakıldığında 2010-2020 yılları arasında Türkçe eğitimi alanında nicel araştırma yöntemleri kullanılarak yapılan doktora tezlerinde 31 konunun ele alındığı görülmektedir. Konu olarak araştırmacıların en çok bir yöntem, yaklaşım veya modelin okuma becerisine olan etkisini (\%10.25) ele aldığı tespit edilmiştir. Dağılıma bakıldığında bunu yaklaşım, yöntem veya modelin yazma becerisine etkisi (\%7.69), duyuşsal özelliklerle dil becerisi ilişkisi (\%7.69), yaklaşım, yöntem veya modelin dinleme becerisine etkisi (\%6.41), edebi türün dil eğitimine etkisi (\%6.41), yaklaşım, yöntem veya modelin konuşma becerisine etkisi (\%5.12), bilgisayar destekli eğitimin ana dili eğitimine etkisi (\%5.12) ve yapılandırımış eğitim ortamının dil becerilerine etkisi (\%5.12) konularının takip ettiği görülmektedir. Tabloda birer kez ele alınan konuların olduğu da görülmektedir.

Tezlerin Yöntemsel Özellikler (Araştırma Deseni, Veri Toplama Araçları, Veri Analiz Yöntemleri, Örneklem Seçim Yöntemi, Örneklem Büyüklüğü) Bakımından Dağılımı

Tezlerde kullanılan araştırma desenlerinin dağılım oranları Tablo 3'te gösterilmiştir.

Tablo 3.

Tezlerin Desenlere Göre Dağılımları

\begin{tabular}{|c|c|c|c|c|c|}
\hline Araştırma Deseni & & $\mathrm{f}$ & $\%$ & $\begin{array}{c}\text { Toplam } \\
\mathrm{f}\end{array}$ & $\begin{array}{c}\text { Toplam } \\
\%\end{array}$ \\
\hline \multirow[t]{3}{*}{ Deneysel } & Ön test son-test kontrol gruplu desen & 24 & 30.76 & \multirow{3}{*}{49} & \multirow{3}{*}{62.81} \\
\hline & $\begin{array}{l}\text { Ön test son-test kontrol gruplu desen } \\
\text { yarı deneysel desen }\end{array}$ & 22 & 28.20 & & \\
\hline & Tek gruplu ön test son test & 3 & 3.84 & & \\
\hline \multirow[t]{2}{*}{ Tarama } & İlişkisel & 16 & 20.51 & \multirow[t]{2}{*}{29} & \multirow[t]{2}{*}{37.17} \\
\hline & Betimsel & 13 & 16.66 & & \\
\hline
\end{tabular}

Tablo 3 incelendiğinde Türkçe eğitimi alanında nicel araştırma yöntemleri kullanılarak hazırlanan doktora tezlerinde deneysel desenlerin ve tarama desenlerinin kullanıldığı görülmektedir. Tezlerin \% 62.81'i deneysel desenler, \%37.17'si ise tarama desenleri kullanılarak hazırlanmıştır. Tezler hazırlanırken daha çok deneysel çalışmaların yapıldığı anlaşıımaktadır. Deneysel desenler içerisinde 
ön test-son test kontrol gruplu desenlerin oranı \%30.76'dır ve diğer desenlere nazaran daha fazla kullanılmıştır. Tarama çalışmalarında ise ilişkisel taramaların betimsel taramalara nazaran daha çok olduğu görülmektedir.

Tezlerde kullanılan örneklem seçim yöntemlerine dair elde edilen bilgiler tablo 4 'te sunulmuştur.

Tablo 4.

Tezlerin Örneklem Seçim Yöntemine Göre Dağılımı

\begin{tabular}{lcc}
\hline Örneklem Seçim Yöntemi & $\mathrm{f}$ & $\%$ \\
\hline Basit Seçkisiz Örneklem & 9 & 11.53 \\
\hline Tabakalı Örnekleme & 8 & 10.25 \\
\hline Kolay Ulaşılabilir Örnekleme & 3 & 3.84 \\
\hline Küme Örnekleme & 2 & 2.56 \\
\hline Uygun Örnekleme & 3 & 3.84 \\
\hline Amaçlı Örnekleme & 5 & 6.41 \\
\hline Evrenin Tamamı & 2 & 2.56 \\
\hline Belirtilmeyenler & 46 & 58.97 \\
\hline
\end{tabular}

Tablo 4'e göre hazırlanan tezlerin \%58.97'sinde örneklem seçim yöntemine yer verilmediği görülmektedir. Bu tür çalışmalarda tezin yürütüldüğü grup hakkında ayrıntılı bilgi verme yoluna gidildiği görülmüştür. Tezlerde örneklem seçim yöntemlerinden en çok basit seçkisiz örnekleme (\%11.53) yönteminin kullanıldığı görülmektedir. En az kullanılan örneklem seçim yöntemi küme örnekleme (\%2.56) yöntemidir. Evrenin tamamına ulaşılan tezlerin oranı ise \%2.56'dır.

Tezlerdeki örneklem/çalışma grubu büyüklüğüne dair elde edilen bulgular tablo 5'te gösterilmiştir.

Tablo 5.

Tezlerin Örneklem/Çalışma Grubu Büyüklüğüne Göre Dağııımı

\begin{tabular}{lcc}
\hline Örneklem/Çalışma Grubu Büyüklüğü & $f$ & $\%$ \\
\hline $0-20$ & 2 & 2.56 \\
\hline $21-40$ & 10 & 12.82 \\
\hline $41-60$ & 16 & 20.51 \\
\hline $61-80$ & 13 & 16.66 \\
\hline $81-100$ & 6 & 7.69 \\
\hline $101-150$ & 6 & 7.69 \\
\hline $151-200$ & 5 & 6.41 \\
\hline $201-300$ & 3 & 3.84 \\
\hline $301-600$ & 13 & 16.66 \\
\hline $601-1000$ & 2 & 2.56 \\
\hline 1001 ve üzeri & 2 & 2.56 \\
\hline
\end{tabular}

Tablo 5 incelendiğinde Türkçe eğitimi alanında nicel araştırma yöntemleriyle hazırlanan doktora tezlerinde en çok çalışmanın 41-60 kişiden oluşan örneklem/çalışma grupları (\%20.51) üzerinde yapıldığı görülmektedir. Tezlerde 0-20 kişiden oluşan örneklemler (\%2.56), 601-1000 kişiden oluşan örneklemler (\%2.56) ile 1001 kişi ve üstünden oluşan örneklemler (\%2.56) daha az tercih edilmiştir.

Tezlerde kullanılan veri toplama araçlarına dair bulgular tablo 6'da gösterilmiştir.

Tablo 6.

Tezlerin Veri Toplama Araçlarına Göre Dağılımı

\begin{tabular}{lcc}
\hline Veri Toplama Araçları & $f$ & $\%$ \\
\hline Anket & 11 & 14.10 \\
\hline
\end{tabular}


Türkçe Eğitimi Alanında Nicel Araştırma Yöntemleri Kullanılarak Yapılan Doktora Tezlerindeki Eğilimler

\begin{tabular}{lcc}
\hline Ölçek & 53 & 67.94 \\
\hline Başarı Testi & 27 & 34.61 \\
\hline Kişilik/Algı/Tutum/ilgi/Yetenek Testleri & 17 & 21.79 \\
\hline Bilgi Formu & 24 & 30.76 \\
\hline Envanter & 4 & 5.12 \\
\hline
\end{tabular}

Tablo 6'ya bakıldığında incelenen doktora tezlerinde veri toplama aracı olarak çoğunlukla ölçek (\% 64.94), başarı testi (\% 34.61) ve bilgi formu (\% 30.76) kullanıldığı görülmektedir. Kullanılan bir diğer veri toplama aracı envanterlerin ise \%5.12 oranla en az kullanılan araç olduğu görülmektedir.

Incelenen tezlerin kullanılan veri analizi yöntemlerine göre dağılımı Tablo 7'de gösterilmiştir.

Tablo 7.

Tezlerin Veri Analiz Yöntemine Göre Dağılımı

\begin{tabular}{|c|c|c|c|}
\hline \multicolumn{2}{|c|}{ Veri Analiz Yöntemleri } & $\mathrm{f}$ & $\%$ \\
\hline Betimsel & $\begin{array}{l}\text { Frekans, Yüzde, Aritmetik } \\
\text { Ortalama, Standart Sapma, Mod, } \\
\text { Ortanca, Çarpıklık, Basıklık }\end{array}$ & 40 & 51.28 \\
\hline \multirow[b]{2}{*}{ Kestirisel } & $\begin{array}{l}\text { Parametrik Testler (Anova, T Testi, } \\
\text { Pearson Korelasyon, Regresyon, } \\
\text { Manova, Ancova) }\end{array}$ & 66 & 84.61 \\
\hline & $\begin{array}{l}\text { Nonparametrik Testler (Ki-Kare, } \\
\text { Wilcoxon, Mann-Whitney U, } \\
\text { Spearman Korelasyon, Friedman, } \\
\text { Kruskal Wallis) }\end{array}$ & 27 & 34.61 \\
\hline
\end{tabular}

Tablo 7 incelendiğinde tezlerde kullanılan veri analiz yöntemlerinin betimsel ve kestirisel analizler olarak sınıflandııılı̆̆ı anlaşılmaktadır. Tablodan tezlerde kestirisel analizlerin daha çok kullanıldığı görülmektedir. Tabloya göre tezlerin \%84.61'inde parametrik testler, \%34.61'inde nonparametrik testler kullanılmıştır. 40 tezde ise yani tezlerin $\% 51.28$ 'inde betimsel analiz yöntemlerinin kullanıldığı görülmektedir. Analiz yöntemlerinin birlikte kullanıldığı tezlerin olduğu da çalışma sırasında tespit edilmiştir.

\section{Tezlerin Seçilen Hedef Kitle Bakımından Dağılımı}

Tablo 8'de incelenen tezlerin yöneldiği hedef kitleye göre dağılımı gösterilmiştir.

Tablo 8.

Tezlerin Hedef Kitlelerine Göre Dağılımı

\begin{tabular}{lcc}
\hline Hedef Kitle & $f$ & $\%$ \\
\hline Yabancı Dil Olarak Türkçe Öğrenenler & 7 & 8.97 \\
\hline Ortaokul Öğrencileri & 51 & 65.38 \\
\hline Yurt Dışındaki Türk Öğrenciler & 3 & 3.84 \\
\hline Balkan Coğrafyasında Yaşayan Türk Gençleri & 1 & 1.28 \\
\hline Öğretmen Adayları & 8 & 10.25 \\
\hline Öğretmenler & 2 & 2.56 \\
\hline Orta Öğretim Öğrencileri & 1 & 1.28 \\
\hline illkokul Öğrencileri & 2 & 2.56 \\
\hline Türk Soylu Öğrenciler & 3 & 3.84
\end{tabular}


Tablo 8 gözden geçirildiğinde tezlerin \%65.38'inin ortaokul öğrencileriyle yapıldığı görülmektedir. Bu oran 51 öğrenciye denk gelmekte ve en çok ortaokul öğrencileriyle çalışma yapıldığı anlaşılmaktadır. Sonrasında ise öğretmen adayları (\%10.25) ve yabancı dil olarak Türkçe öğrenenlerle (\%8.97) tez çalışmalarının yapıldığı görülmektedir. Hedef kitle olarak en az orta öğretim öğrencileri ve Balkan coğrafyasında yaşayan Türk gençlerinin seçildiği tablodan anlaşılmaktadır.

\section{Tezlerdeki Hedef Kitlenin Örneklem/Çalışma Grubu Büyüklüğüne Göre Dağılımı}

Tablo 9'da tezlerdeki hedef kitlenin örneklem/çalışma grubu büyüklüğüne göre dağılımı gösterilmiştir. Tabloda frekans değerlerine yer verilmiştir.

Tablo 9.

Hedef Kitlenin Örneklem/Çalışma Grubu Büyüklüğüne Göre Dağılımı

\begin{tabular}{|c|c|c|c|c|c|c|c|c|c|c|c|}
\hline & & & & Örne & lem / & alışma & cubu $\mathrm{Bi}$ & yüklüğ & & & \\
\hline Hedef Kitle & $0-20$ & $\begin{array}{l}21- \\
40\end{array}$ & $\begin{array}{l}41- \\
60\end{array}$ & $\begin{array}{l}61- \\
80\end{array}$ & $\begin{array}{l}81- \\
100\end{array}$ & $\begin{array}{l}101- \\
150\end{array}$ & $\begin{array}{l}151- \\
200\end{array}$ & $\begin{array}{l}201- \\
300\end{array}$ & $\begin{array}{l}301- \\
600\end{array}$ & $\begin{array}{l}601- \\
1000\end{array}$ & $\begin{array}{c}1001 \\
\text { ve } \\
\text { üstü }\end{array}$ \\
\hline $\begin{array}{l}\text { Yabancı Dil } \\
\text { Olarak Türkçe } \\
\text { Öğrenenler }\end{array}$ & & 3 & & 1 & & 1 & 1 & & 1 & & \\
\hline $\begin{array}{l}\text { Ortaokul } \\
\text { Öğrencileri }\end{array}$ & 1 & 6 & 14 & 7 & 5 & 3 & 3 & 1 & 8 & 2 & 1 \\
\hline $\begin{array}{l}\text { Yurt Dışındaki } \\
\text { Türk } \\
\text { Öğrenciler }\end{array}$ & & & 1 & & & 1 & 1 & & & & \\
\hline $\begin{array}{l}\text { Balkan } \\
\text { Coğrafyasında } \\
\text { Yaşayan Türk } \\
\text { Gençleri }\end{array}$ & & & & & & & & & 1 & & \\
\hline $\begin{array}{l}\text { Öğretmen } \\
\text { Adayları }\end{array}$ & & & 1 & 5 & 1 & & & 1 & & & \\
\hline Öğretmenler & & 1 & & & & & & & 1 & & \\
\hline $\begin{array}{l}\text { Orta Öğretim } \\
\text { Öğrencileri }\end{array}$ & & & & & & & & & 1 & & \\
\hline $\begin{array}{l}\text { İlkokul } \\
\text { Öğrencileri }\end{array}$ & 1 & & & & & & & & 1 & & \\
\hline $\begin{array}{l}\text { Türk Soylu } \\
\text { Öğrenciler }\end{array}$ & & & & & & 1 & & 1 & & & 1 \\
\hline
\end{tabular}

Tablo 9 incelendiğinde ortaokul öğrencileri üzerinde her örneklem/çalışma grubu büyüklüğünde tez hazırlandığı görülmektedir. 1001 kişi ve üstündeki örneklem/çalışma grupları en büyük gruplardır. Bu gruplarda Türk soylu öğrencilerle ve ortaokul öğrencileriyle yapılan çalışmalardan birer tane yer aldığı görülmektedir. En küçük örneklem/çalışma grubunu oluşturan 020 kişilik gruplarla yapılan çalışmalara bakıldığında ilkokul ve ortaokul öğrencileri üzerine yapılan çalışmalardan birer tane bulunduğu görülür. Ortaokul öğrencileri en çok üzerinde tez çalışması yapılan hedef kitledir. Tezlerde en çok 41-60 kişiden oluşan örneklem/çalışma grupları tercih edilmiştir ve bunların 14 tanesi ortaokul öğrencilerini hedef kitle olarak almışır. Ortaokul öğrencileri üzerine yapılan tezlerde daha büyük örneklem/çalışma gruplarıyla çalışıldığı görülmektedir. 
Tezlerde Kullanılan Desenlerin Örneklem/Çalışma Grubu Büyüklüğüne Göre Dağılımı

Tablo $10^{\prime}$ da tezlerde kullanılan desenlerin örneklem/çalışma gruplarının büyüklüğüne göre dağılımı sunulmuştur. Tabloda frekans değerlerine yer verilmiştir.

Tablo 10.

Desenlerin Örneklem/Çalışma Grubu Büyüklüğüne Göre Dağılımı

\begin{tabular}{|c|c|c|c|c|c|c|c|c|c|c|c|}
\hline & \multicolumn{11}{|c|}{ Örneklem / Çalışma Grubu Büyüklüğü } \\
\hline & $0-20$ & $\begin{array}{c}21- \\
40\end{array}$ & $\begin{array}{c}41- \\
60\end{array}$ & $\begin{array}{l}\text { 61- } \\
80\end{array}$ & $\begin{array}{l}81- \\
100\end{array}$ & $\begin{array}{l}101- \\
150\end{array}$ & $\begin{array}{c}151 \\
-\end{array}$ & $\begin{array}{c}201 \\
-\end{array}$ & $\begin{array}{c}301 \\
-\end{array}$ & 601 & $\begin{array}{l}100 \\
1 \text { ve }\end{array}$ \\
\hline Desen & & & & & & & 200 & 300 & 600 & 1000 & üstü \\
\hline Deneysel & 2 & 8 & 16 & 12 & 5 & 3 & 3 & & & & \\
\hline Tarama & & 2 & & 1 & 1 & 3 & 2 & 3 & 13 & 2 & 2 \\
\hline
\end{tabular}

Tablo 10'a bakıldığında tarama deseni kullanılarak hazırlanan tezlerde deneysel desenlerle hazırlanan tezlere nazaran daha büyük gruplarla çalışıldığı görülmektedir. Deneysel çalışmalardaki örneklem/çalışma gruplarının en büyüğü 151 ila 200 kişiden oluşan gruplardan oluşmaktadır. Tarama çalışmalarında ise 1001 kişi ve üstündeki sayılardan oluşan gruplarla çalışıldığı görülmektedir. Deneysel çalışmalarda en küçük örneklem/çalışma grubu olan 20'den az kişiden oluşan gruplarla 2 çalışma yapıldığı görülürken bu büyüklükteki gruplarla tarama çalışmalarının yapılmadığı görülmektedir. Deneysel desenlerin kullanıldığı tezlerde en çok 41 ila 60 kişiden oluşan örneklem/çalışma grupları tercih edilmiştir. Tarama desenleri kullanılan tezlerde ise 301 ila 600 kişiden oluşan gruplar daha çok tercih edilmiştir.

Tezlerde Kullanılan Desenlerin Hedef Kitleye Göre Dağılımı

Tablo 11 'de tezlerde kullanılan nicel araştırma desenlerinin çalışma yapılan hedef kitlelere göre dağılımı gösterilmiştir.

Tablo 11.

Desenlerin Hedef Kitleye Göre Dağılımı

\begin{tabular}{|c|c|c|c|c|}
\hline & \multicolumn{4}{|c|}{ Desenler } \\
\hline & \multicolumn{2}{|c|}{ Deneysel } & \multicolumn{2}{|c|}{ Tarama } \\
\hline Hedef Kitle & $f$ & $\%$ & f & $\%$ \\
\hline Yabancı Dil Olarak Türkçe Öğrenenler & 3 & 3.84 & 4 & 5.12 \\
\hline Ortaokul Öğrencileri & 37 & 47.43 & 14 & 17.94 \\
\hline Yurt Dışındaki Türk Öğrenciler & 1 & 1.28 & 2 & 2.56 \\
\hline $\begin{array}{l}\text { Balkan Coğrafyasında Yaşayan Türk } \\
\text { Gençleri }\end{array}$ & - & - & 1 & 1.28 \\
\hline Öğretmen Adayları & 7 & 8.97 & 1 & 1.28 \\
\hline Öğretmenler & - & - & 2 & 2.56 \\
\hline Orta Öğretim Öğrencileri & - & - & 1 & 1.28 \\
\hline
\end{tabular}




\begin{tabular}{lcccc}
\hline İlkokul Öğrencileri & 1 & 1.28 & 1 & 1.28 \\
\hline Türk Soylu Öğrenciler & - & - & 3 & 3.84 \\
\hline
\end{tabular}

Tablo 11 incelendiğinde deneysel çalışmaların ortaokul öğrencileri üzerinde daha çok yapııdığı görülmektedir. Tüm tezler içerisinde ortaokul öğrencileri üzerinde yapılan deneysel çalışmaların oranı \%47.43'tür. Ortaokul öğrencileriyle hazırlanan tarama çalışmalarının incelenen tezler içerisindeki oranı ise \%17.94'tür ve tarama çalışmaları içindeki en büyük orandır. Tabloya bakıldığında öğretmen adayları üzerinde toplam 8 nicel çalışma yapılmıştır. Bu tezlerin 7'si (\%8.97) deneysel modellerle, sadece 1'i (\%1.28) tarama modelleriyle gerçekleştirilmiştir. Balkan coğrafyasında yaşayan Türkler, öğretmenler, orta öğretim öğrencileri ve Türk soylu öğrenciler üzerine deneysel çalışma yapılmadığı tablodan anlaşılmaktadır.

\section{Tartışma ve Sonuç}

Doktora tezlerinde araştırmacıdan alana nitelikli ve özgün katkılarda bulunması beklenir. Doktora tezlerinin incelendiği çalışmalar alandaki gelişimin görülmesi bakımından önem arz eder. Bu çalışmada Türkçe eğitimi alanında 2010-2020 yılları arasında nicel araştırma yöntemleri kullanılarak yapılan doktora tezlerindeki eğilimler incelenmiştir. Bu kapsamda belirtilen yıllar arasında toplam 323 doktora tezine ulaşımış, bu tezlerin 78'inin sadece nicel araştırma yöntemleri kullanılarak hazırlandığı tespit edilmiştir.

Yapılan bu çalışmayla Türkçe eğitimi alanında nicel araştırma yöntemleri kullanılarak en fazla 2011, en az 2020 yılında doktora tezi hazırlandığı anlaşılmaktadır. Nicel araştırma yöntemleriyle hazırlanan tezlerin toplam sayısı nitel ve karma yöntemlerle hazırlanan tezlere göre daha azdır. Çalışma sonucunda nitel araştırma yöntemleri kullanılarak hazırlanan tezlerin sayıca daha çok olduğu görülmüştür. Son yıllarda karma yöntemlerle hazırlanan tezlerin sayısında artış olduğu da tespit edilmiştir. Boyacı ve Demirkol'un (2018) yaptığı çalışmada nicel araştırma yöntemleriyle hazırlanan tezlerin daha düşük oranda olduğu, nitel araştırma yöntemleriyle hazırlanan tezlerin daha büyük bir oranda olduğu belirtilmiştir. Araştırmacıların ulaştığı sonuçlar bu çalışmadaki sonuçlarla örtüşmektedir.

Tezlerde incelenen konulara bakıldığında 31 farklı konuda çalışma yapıldığı görülmüştür. Konu olarak bir yaklaşım, yöntem veya modelin okuma becerisine olan etkisinin incelendiği tezlerin sayısının en yüksek olduğu tespit edilmiştir. Dinleme becerisi üzerine hazırlanan tezlerin sayısına bakıldığında bu becerinin ihmal edildiği söylenebilir. Genel olarak tezlerin konularına bakıldığında araştırmacıların seçilen bir yaklaşım, yöntem veya modelin dil eğitimindeki etkisini araştırdıkları anlaşılmaktadır. Yapılan tezlerde dil becerilerine eğilimlerin fazla olduğu görülmektedir. Bu durum Yağmur Şahin vd. (2013) ve Özçakmak'ın (2017) çalışmasındaki bulgulara paralellik göstermektedir.

Araştırma desenlerine göre tezlerin dağılımına bakıldığında deneysel desenlerin ve tarama desenlerinin kullanıldığı görülmektedir. Deneysel desenlerin tarama desenlerine göre daha büyük bir orana sahip olduğu çalışma sonucunda tespit edilmiştir. Ön test-son test kontrol gruplu desen 24 , ön test- son test kontrol gruplu yarı deneysel desen 22, tek gruplu ön test-son test deneysel desen ise 3 tezde kullanılmıştır ve toplam 49 tez deneysel desenle hazırlanmıs olup bu sayı oran olarak tezlerin \%62.81'ine tekabül etmektedir. Tarama desenleri içerisinde ise daha çok ilişkisel tarama deseni kullanılmıştır. Bu bulgular Varışoğlu, Şahin ve Göktaş'ın (2013) çalışmalarında ulaştıkları bulgulara benzerlik göstermektedir.

Tek grup ön test-son test modeli zayıf deneysel desen olarak bilinir. Bu desen deneysel çalışmalarda olması gereken kimi özellikleri taşımaz. Bu sebeple iç geçerlilik şartlarını tam olarak yerine getirememektedir ve uygulamada kullanılması çok tavsiye edilmez (Özmen, 2014). Bu yönüyle doktora tezlerinde zayıf deneysel desenlerin kullanılması eleştirilebilir.

Veri toplama araçları olarak en çok ölçeklerin kullanıldığı görülmüştür. Ölçeklerden sonra başarı testleri ve bilgi formları gelmektedir. En düşük sayıda envanterlerin kullanıldığı görülmektedir. Eyüp (2020) yaptığı çalışmada veri toplama araçları bakımından benzer sonuçlara ulaşmış, ölçeklerin tezlerde daha çok kullanıldı̆ıını ifade etmiştir. 
Yapılan çalışmayla Türkçe eğitimi alanında nicel araştırma yöntemleriyle hazırlanan tezlerde daha çok kestirisel istatistiklerin diğer adıyla anlam çıkartıcı istatistiklerin yapıldığı görülmüştür. Anlam çıkartııı istatistiklerde amaç, örneklem özelliklerinden yola çıkarak evren karakterini tanımak, evrenin özelliklerini kestirebilmektir. Bunun yanında örneklemde bulunan değişkenler arası ilişkiye bağlı olarak evrendeki ilişki üzerine kestirim yapmak da amaçlanır (Büyüköztürk, Çokluk ve Köklü, 2020). Eyüp (2020) yaptığı çalışmada incelediği tezlerde kestirisel analizlerin betimsel analizlere göre daha çok kullanıldığını tespit etmiş ve bu çalışma bulgularıyla uyumlu bir sonuç ortaya konulduğu görülmüştür. Ancak Yağmur Şahin vd.'nin (2013) yaptığı çalışmaya göre daha fazla betimsel analizlerin yapıldığı görülmektedir.

Veri analizi yapılırken parametrik veri setleriyle daha fazla çalışıldığı, kestirisel analizler içinde parametrik testlerin daha fazla kullanıldığı anlaşımıştır. Bir çalışmada parametrik istatistikler kullanılıyorsa araştırmacının dağılımın normal olduğuna dair yeterli kanıta sahip olması gerekir. Ayrıca gruplar arası karşılaştırma yapılacaksa örneklemlerin ait olduğu evrendeki varyansları eşit olmalıdır (Büyüköztürk vd., 2020).

Doktora tezlerinde kullanılan örneklem seçim yöntemleri ele alındığında basit seçkisiz örneklemin diğer örneklem seçim yöntemlerine göre daha çok kullanıldığı görülmüştür. İkinci sırada ise tabakalı örnekleme yönteminin geldiği tespit edilmiştir. Küme örnekleme yöntemi ise en az kullanılandır. Evrenin tamamına ulaşıldığını ifade eden tezler de bulunmaktadır. Bulgularda dikkat çeken nokta doktora tezlerinin \%58.97'sinde örneklem seçim yönteminin belirtilmeyişidir. Bu durum örneklem oluşturma sürecinin şeffaflığı noktasında eleştirilere sebep olabilir. Eyüp'ün (2020) yaptığı çalışmada incelediği tezlerden örneklem seçim yöntemlerine dair elde ettiği bulguların bu çalışmanın bulgularıyla uyumlu olduğu görülmüştür.

Tezlerdeki örneklem/çalışma grubu büyüklüklerine bakıldığında 41 ila 60 kişiden oluşan örneklem gruplarının daha çok tercih edildiği görülmektedir. 20'den az kişiden oluşan gruplar, 601 ila 1000 kişiden oluşan gruplar ve 1001 'den fazla kişiden oluşan gruplar üzerinde ikişer tane çalışma yapılmıştır. Bu büyüklüklerdeki örneklem/çalışma grupları daha az tercih edilmiştir. Örneklem/çalışma grupları büyüdükçe tarama desenlerinin kullanımı da artmıştır Örneklem/çalışma grupları küçüldükçe deneysel çalışmaların daha çok kullanıldığı tespit edilmiştir. Genel olarak bir yorum yapıldığında tezlerin tam olarak yarısı 21 ila 80 kişi aralığında olan gruplar üzerinde yapıldığı tespit edilmiştir. Varışoğlu vd.'nin (2013) çalışmasında Türkçe eğitimi alanındaki çalışmalarda 31-100 kişi arasında değişen örneklem grupları ve 101-300 kişi arasında değişen örneklem gruplarının daha fazla yer aldığı belirtilmiştir. Çalışmada 1000 'den fazla kişiden oluşan örneklem gruplarının en az tercih edildiği ifade edilmiştir.

Hedef kitleler bakımından tezler incelendiğinde ortaokul öğrencileri üzerine daha fazla çalışma yapıldığı görülmüştür. Tezlerin yarıdan fazlası ortaokul öğrencileri üzerine hazırlanmıştır. İkinci sırada öğretmen adayları üzerine hazırlanan tezler gelmektedir. Devamında yabancı dil olarak Türkçe öğrenenler üzerine yapılan tezler gelmektedir. Özçakmak'ın (2017) yaptığı çalışma incelendiğinde lisansüstü tezlerdeki hedef kitleler üzerine yaptığı tespitlerin bu çalışma bulgularıyla paralellikler gösterdiği görülmüştür.

Tezlerde farklı büyüklüklerde örneklem/çalışma gruplarıyla çalışımıştır. Ortaokul öğrencileri ve Türk soylu öğrenciler üzerine yapılan tezlerde en büyük örneklem/çalışma grupları tercih edilmiş ve bu tezlerde tarama deseni kullanılmıştır. En küçük örneklem/çalışma grubuyla (20'den az kişi) yapılan tezler ise ortaokul ve ilkokul öğrencileriyle yapılmıştır ve deneysel desenle modellenmiştir. 41-60 kişiden oluşan gruplarla yapılan tezlerin sayısı 16'dır ve tezlerde en çok tercih edilen örneklem/çalışma grubu büyüklüğü bu aralıktır. Bu örneklem büyüklüğünde ortaokul öğrencileriyle yapılan çalışmaların sayısı 14'tür.

Desenlerin örneklem büyüklüğüne göre dağılımı incelendiğinde tarama desenleriyle hazırlanan tezlerde deneysel desenlerle hazırlanan tezlere göre daha büyük örneklem/çalışma gruplarıyla süreç yürütülmüştür. Tarama çalışmaları ile büyük kitlelerin özelliklerini betimlemek amaçlanır. Diğer araştırmalara nazaran daha büyük örneklemlerle çalışmalar yapılır (Büyüköztürk vd.,2016). Deneysel desenlere bakıldığında ise daha küçük örneklem/çalışma gruplarına eğilimin olduğu görülmektedir. 20'den az kişiden oluşan gruplarla yapılan tezlerde deneysel desenlerin, 
1001'den fazla kişiden oluşan gruplarla yapılan tezlerde ise tarama desenlerinin kullanıldığı tespit edilmiştir.

Desenlerin hedef kitlelere göre dağılımı incelendiğinde ortaokul öğrencileri ve öğretmen adayları üzerine yapılana tezlerde daha çok deneysel desenler kullanılmıştır. Türk soylu öğrenciler, öğretmenler, orta öğretim öğrencileri üzerine yapılan tezlerin tamamı tarama deseniyle modellenmiştir. Eyüp (2020) yaptığı çalışmada Türkçe öğretmenlerine yönelik yapılan tezlerde deneysel çalışmaların yapılmadığını ifade etmiştir. Yabancı dil olarak Türkçe öğrenenlerle 3 tez deneysel desenle, 4 tez tarama deseniyle hazırlanmıştır ve daha dengeli bir dağılım görülmektedir.

Sonuç olarak Türkçe eğitimi alanında yapılan doktora tezleri incelendiğinde nicel araştırma yöntemleriyle hazırlanan doktora tezlerinin sayısı diğer yöntemlerle hazırlanan doktora tezlerinin sayısından azdır. Son yıllarda karma yöntemlere olan eğilim artmıştır. Doktora tezlerinde dil becerileri merkezli konular ve uygulanan yöntemin etkisi üzerine çalışmalar yoğunluktadır. Deneysel desenlerle üretilen tezlerin oranı daha yüksektir. Örneklem seçim yöntemlerinin tezlerin yarısından fazlasında belirtilmemiş olması dikkat çekicidir. Örneklem/çalışma grubu büyüklüğü bakımından en çok 41 ila 60 kişiden oluşan gruplar tercih edilmiştir. Tezlerde en büyük örneklem/çalışma grupları ortaokul öğrencilerinden ve Türk soylu öğrencilerden oluşmaktadır. Bu gruplar 1001 kişiden büyük örneklem gruplarıdır. Ölçekler en çok kullanılan veri toplama aracıdır. Tezlerde en çok parametrik testlerle veri analizi yapılmıştır. Yapılan tezlerin yarısından fazlası ortaokul öğrencileri üzerine gerçekleştirilmiş olup bunların büyük çoğunluğu deneysel desenlerle yürütülmüştür.

Lisansüstü tezleri kullanılan yöntemler çerçevesinde sınırlandırarak farklı incelemeler yapmak mümkündür. Nitel ve karma araştırma yöntemleri çerçevesinde lisansüstü tezler incelenebilir. Bu çalışmada nicel araştırma yöntemleri temel alındığı için meta-analiz çalışmaları yapacak araştırmacılara ipucu verebileceği düşünülmektedir.

Araştırma deseni olarak sadece iki desen kullanılmış olması farklı desenlerin de kullanılarak doktora tezlerinin hazırlanması gerektiğini akla getirmektedir. Tezlerde örneklem belirleme süreçlerinde daha dikkatli davranılması faydalı olabilir. Tezlerde örneklem seçim yöntemlerinin belirtilmemesi, örneklem oluşturma süreçlerinin yetersiz ve eksik olarak ifade edilmesi tezlere eleştirel gözle bakılmasına neden olmaktadır.

Çalışmada hedef kitleler bakımından tezler incelendiğinde ortaokul öğrencileri üzerine yoğunlaşma olduğu görülmüştür. Belirtilen diğer hedef kitleler üzerine çalışmalar artırılabilir. Alandaki öğretim elemanları, öğrenci velileri gibi hedef kitleler üzerinde de tez çalışmaları yapılabilir.

Bir yöntemin etkisi veya değişkenler arasındaki ilişkilerin çalışıldığı tez çalışmaları çoğunluktadır. Konu seçiminde daha farklı yönelimler olabilir. Doktora tezlerinde disiplinlerarası çalışmalar yapılabilir. Bir probleme dönük uygulamalı çözüm önerilerine, tasarım geliştirme araştırmalarına ve çağın gerektirdiği yeniliklere dönük çalışmalara yönelmek doktora tezlerinin üretim mantığına uygun bir yaklaşım olabilir.

\section{Araştırma ve Yayın Etiği}

Bu çalışmada "Yükseköğretim Kurumları Bilimsel Araştırma ve Yayın Etiği Yönergesi" kapsamında uyulması belirtilen tüm kurallara uyulmuştur. Yönergenin ikinci bölümü olan "Bilimsel Araştırma ve Yayın Etiğine Aykırı Eylemler" başlığı altında belirtilen eylemlerden hiçbiri gerçekleştirilmemiştir.

\section{Yazarların Katkı Oranı}

Bu çalışma yazarın kendisi tarafından tek başına hazırlanmıştır.

\section{Çıkar Çatışması}

Yapılan bu çalışmada dolaylı veya dolaysız herhangi bir çıkar çatışması teşkil edebilecek durum ya da ilişki yoktur. 


\section{Kaynaklar}

Boyacı, S. ve Demirkol, S. (2018). Türkçe eğitimi alanında yapılan doktora tezlerinin incelenmesi. Ana Dili Eğitimi Dergisi, 6(2), 512-531.

Büyüköztürk, Ş., Çakmak, E. K., Özcan, Ö.E., Karadeniz, Ş. ve Demirel, F. (2016). Bilimsel araştırma yöntemleri (21. Baskı). Ankara: Pegem Akademi.

Büyüköztürk, Ş., Çokluk, Ö. ve Köklü, N. (2020). Sosyal bilimler için istatistik. Ankara: Pegem Akademi.

Can, A. (2019). Spss ile bilimsel araştırma sürecinde nicel veri analizi (19. Baskı). Ankara: Pegem Akademi.

Cin Şeker, Z. (2020). Dinleme ve konuşma becerilerine yönelik lisansüstü tezlerin anahtar kelimeleri üzerine bir inceleme: Betimsel analiz. RumeliDE Dil ve Edebiyat Araştırmaları Dergisi, 19, 128140.

Creswell, J. W. (2017). Araştırma deseni nitel, nicel ve karma yöntem yaklaşımları. (Çev. S. B. Demir). Ankara: Eğiten Kitap.

Demirbaş, M. (2014). Bilimsel araştırma ve özellikleri. M. Tekin (Ed.), Kuramdan uygulamaya eğitimde bilimsel araştırma yöntemleri içinde (ss. 3- 19). Ankara: Pegem Akademi.

Direkçi, B., Akbulut, S. ve Şimşek, B. (2020). Türkçe eğitimi alanında yapılan değerler eğitimi tezlerinin incelenmesi. Journal of World of Turks,12(2),117-140.

Doğan, Y. ve Özçakmak, H. (2014). Dinleme becerisinin eğitimi üzerine yapılan lisansüstü tezlerin değerlendirilmesi. Ana Dili Eğitimi Dergisi, 2(2), 90-99.

Deniz, K. ve Karagöl, E. (2016). Eğitim bilimleri alanındaki lisansüstü tez başlıklarının kelime sayısı ve söz dizimi bakımından incelenmesi. Ana Dili Eğitimi Dergisi, 4(2), 248-260.

Ekiz, D. (2020). Bilimsel araştırma yöntemleri (6. Baskı). Ankara: Anı Yayıncılık.

Eyüp, B. (2020). Türkçe öğretmenleri ile ilgili yapılan lisansüstü tezlerin eğilimleri: Bir içerik analizi (2000-2019). RumeliDE Dil ve Edebiyat Araştırmaları Dergisi, 21, 536-558.

Gülen Canlı, M. ve Tepeli, Y. (2019). Dil bilgisi öğretimi üzerine yapılmış doktora tezlerinin sistematik incelenmesi. International Journal of Social Science Research, 8(2),60-87.

Güzel, A. (2003). Türkçenin eğitimi-öğretimi bölümlerinde kurulması gerekli görülen anabilim dalları hakkında yeni projelerimiz. Selçuk Üniversitesi Türkiyat Araştırmaları,13,63-86.

Kan, M. K. (2014). Sözbilimsel Yapı Temelli Bir Metindilbilim Çözümlemesi: Türkçe Eğitimi Alanındaki Yüksek Lisans Tezlerinin Sözbilimsel Yapı Özellikleri. (Yayımlanmamış doktora tezi) Ankara Üniversitesi Sosyal Bilimler Enstitüsü, Ankara.

Karagöl,E.(2018). Akademik Yazma Açısından Lisansüstü Tezler (Yayınlanmamış doktora tezi). Gazi Üniversitesi Eğitim Bilimleri Enstitüsü, Ankara.

Karasar, N. (2020). Bilimsel araştırma yöntemi (35. Baskı). Ankara: Nobel Akademik Yayıncılık.

Miles, M. B. ve Huberman, A. M. (2016). Genişletilmiş bir kaynak kitap: Nitel veri analizi. (S. A. Altun, A. Ersoy Çev.). Ankara: Pegem Akademi.

Özçakmak, H. (2017). Türkçe eğitimi lisansüstü araştırmalarında yeni yönelimler (2011-2015). Ulus/ararası Türkçe Edebiyat Kültür Eğitim Dergisi, 6(3), 1607-1618.

Özdemir, S. (2018). Okumaya ilişkin lisansüstü araştırmaların eğilimleri. Ana Dili Eğitimi Dergisi, 6(4), 1161-1178

Özmen, H. (2014). Deneysel araştırma yöntemi. M. Tekin (Ed.), Kuramdan uygulamaya eğitimde bilimsel araştırma yöntemleri içinde (ss. 3- 19). Ankara: Pegem Akademi.

Sevim, O. ve Özdemir Erem, N.H. (2012). Türkçe eğitimi alanındaki yüksek lisans tezlerinin başlıklarına ve özetlerine bir bakış. Uluslararası Türkçe Edebiyat Kültür Eğitim Dergisi Sayı: 1(3), 174-186.

Şahin, A., Çiftçi, B. ve Başbayrak, M. (2020). Teknoloji destekli Türkçe eğitimi tezlerinin eğilimleri. Uluslararası Eğitim Bilim ve Teknoloji Dergisi, 6(2), 98-114.

Şeref, i. ve Karagöz, B. (2019). Türkçe eğitimi akademik alanına ilişkin bir değerlendirme: Web of Science veri tabanına dayalı bibliyometrik inceleme. Dil Eğitimi Araştırmaları Dergisi,5(2).

Temizkan, M. ve Erdevir, M. (2020). Yazılı anlatımla ilgili yüksek lisans tezlerinde kullanılan değişkenler üzerine bir değerlendirme. Ana Dili Eğitimi Dergisi, 8(4), 1218-1244.

Tok, M. ve Potur, Ö. (2015) Yazma eğitimi alanında yapılan akademik çalışmaların eğilimleri (20102014 yılları). Ana Dili Eğitimi Dergisi, 3(4), 1-25. 
Turan, L., Sevim, O. ve Tunagür, M. (2018). Türkçe eğitimi alanındaki doktora tezlerinin özet bölümlerine yönelik bir içerik analizi. Uluslararası Türk Eğitim Bilimleri Dergisi, 11, 29-44.

Varışoğlu, B., Şahin, A. ve Göktaş, Y. (2013). Türkçe eğitimi araştırmalarında eğilimler. Kuram ve Uygulamada Eğitim Bilimleri, 13(3), 1767-1781.

Yağmur Şahin, E., Kana, F., \& Varışoğlu, B. (2013). Türkçe eğitimi bölümlerinde yapılan lisansüstü tezlerin araştırma eğilimleri. International Journal of Human Sciences, 10(2), 356-378.

Yıldırım, A. ve Şimşek, H. (2016). Sosyal bilimlerde nitel araştırma yöntemleri. Ankara: Seçkin Yayıncilık.

\section{Introduction}

\section{Extended Abstract}

In doctoral dissertations, the researcher is expected to make original studies in the field. Original contributions should be made to science with the work done. Academic life develops on the basis of doctoral dissertations. For the researcher, the branch begins with the doctoral thesis. In this respect, doctoral thesis is seen as the most important step in academic life. Academic studies are constantly carried out in the field of Turkish education and the studies are increasing in terms of quantity. Analysis studies to be conducted in the field of Turkish education will ensure that the deficiencies in the field are clearly seen. Such studies will guide researchers in the field. With this study, it was aimed to determine the trends by examining the doctoral dissertations prepared using quantitative research methods in the field of Turkish education between 2010 and 2020 in terms of various characteristics.

\section{Method}

The survey model was used in this study. With the scanning model, it is aimed to describe a past or current situation as it is. The object, individual or event that is the subject of the study is tried to be defined as it exists in its own conditions. The screening researcher can interpret the data obtained by applying to various records such as written documents, statistics, images and sound recordings, pictures by integrating them into a system (Karasar, 2020).

\section{Result and Discussion}

In this study, the trends in doctoral dissertations in the field of Turkish education between 2010-2020 using quantitative research methods were examined. In this context, a total of 323 doctoral dissertations were reached between the years specified, and it was determined that 78 of these theses were prepared using only quantitative research methods.

When the topics of the theses are examined in general, it is seen that the researchers investigate the effect of a chosen method on language education. Considering the number of theses prepared on the listening skill, it can be said that this skill has been neglected. It is seen that the tendencies towards language skills are high in the theses. This situation is parallel to the findings in the study of Yağmur Şahin et al. (2013) and Özçakmak (2017).

Considering the distribution of theses according to research designs, it is seen that experimental designs and scanning designs are used. As a result of the study, it was determined that experimental designs have a higher rate than scanning designs These findings are similar to the findings of Varışoğlu, Şahin, and Göktaş (2013).

When analyzing data, it is understood that more work is done with parametric data sets. In order to use parametric statistics in theses, the researcher must have sufficient evidence that the distribution is normal. If comparisons are to be made between groups, the variances of the samples in the population they belong to should be equal (Büyüköztürk et al., 2020).

It has been observed that scales are mostly used as data collection tools. Achievement tests and information forms comes after. It is seen that the lowest number of inventories are used. Eyüp (2020) reached similar results in terms of data collection tools in his study and stated that scales were used more in theses. 
When the theses were examined in terms of target audiences, it was seen that more studies were conducted on secondary school students. More than half of the theses are prepared on secondary school students. Theses on teacher candidates come second. When Özçakmak's (2017) study was examined, it was seen that the determinations made on the target audiences in the postgraduate theses showed parallels with the findings of this study.

As a result, the rate of doctoral theses prepared by quantitative research methods is lower than the rates of doctoral dissertations prepared by other methods. The trend towards mixed methods has increased in recent years. In doctoral dissertations, studies on language skills-centered issues and the effect of the method are concentrated. The rate of theses produced with experimental designs is higher. It is noteworthy that sample selection methods are not specified in more than half of the theses. The largest sample / study groups in the theses consist of middle school students and students of Turkish origin. These groups are sample groups of more than 1001 people. Scales are the most used data collection tool. In theses, mostly data analysis has been done with parametric tests. More than half of the theses were conducted on secondary school students, and most of them were conducted with experimental designs.

\section{Ek}

\section{Tez Sınıflama Formu}

\section{1- Tez Adı:}

\section{2- Yayın Yılı:}

\section{3- Tez Konusu:}

1- Yaklaşım, yöntem veya modelin okuma becerisine etkisi ( )

2-Yaklaşım, yöntem veya modelin yazma becerisine etkisi ( )

3- Yaklaşım, yöntem veya modelin dinleme becerisine etkisi ( )

4- Yaklaşım, yöntem veya modelin konuşma becerisine etkisi ( )

5- Yaklaşım, yöntem veya modelin dil becerilerine etkisi ( )

6- Duyuşsal özelliklerle dil becerisi ilişkisi ( )

7- Dil bilgisi öğretiminde yaklaşım, yöntem veya modelin etkisi ( )

8- Bilgisayar destekli eğitimin ana dili eğitimine etkisi

9- Yabancılara Türkçe öğretiminde bilgisayar destekli eğitimin başarıya etkisi ( )

10- Yurt dışındaki Türk çocuklarında dil becerileri ( )

11- Öğretim programının dil eğitimindeki etkisi ( )

12- Eğitsel oyunların dil becerilerinin gelişimine etkisi ( )

13- Yabancılara Türkçe öğretiminde öğretmen yeterlilikleri ( )

14- Okuma becerisi ve diğer disiplinlerdeki başarı ilişkisi ( )

15- Işitme engellilerde dil eğitimi ( )

16- Yaklaşım, yöntem veya modelin duyuşsal özelliklere ve başarıya etkisi ( )

17- Yabancılara Türkçe öğretiminde duyuşsal özelliklerle dil becerisi ilişkisi ( )

18- Yazma etkinliklerine yönelik algılar ( )

19- Yapılandırılmış eğitim ortamının dil becerilerine etkisi ( )

20- Türk soylu öğrencilerde Türkçe eğitimi ve duyuşsal özellikler ( )

21- Edebi türün dil eğitimine etkisi ( )

22- Yurt dışındaki Türklerde dil farkındalığı ( )

23- Yaklaşım, yöntem veya modelin kelime öğrenimine etkisi ( )

24- Bibliyoterapinin duyuşsal ve bilişsel özelliklere etkisi ( )

25- Yazma becerisi değerlendirmesi ( )

26- Kelime bilgisi dil becerisi ilişkisi ( )

27- Yabancılara Türkçe öğretiminde ek öğretiminin dil gelişimine etkisi ( )

28- Yabancılara Türkçe öğretiminde dinleme metinlerinin anlaşıırlığı ( ) 
29- İi dillilik temelinde incelemeler ( )

30- Dil becerileri arasındaki ilişki ( )

31- Yabancılara Türkçe öğretiminde dil öğretim sürecinin değerlendirmesi ( )

\section{4- Araştırma Deseni}

1- Tarama Araştırmaları

a- iliş̧kisel ( ) b-Betimsel ( )

2- Deneysel Araştırma

a- Ön test-son test kontrol gruplu desen b- Ön test-son test kontrol gruplu yarı deneysel desen ( )

c- Tek gruplu ön test-son test ( )

3- Tek Denekli Araştırma ( )

4- Korelasyonel Araştırma ( )

5- Nedensel Karşılaştırma ( )

6- Meta-Analiz ( )

\section{5- Örneklem Seçim Yöntemi}

1- Basit seçkisiz örneklem ( )

2-Tabakalı örnekleme ( )

5- Uygun örnekleme ( )

6- Amaçlı örnekleme ( )

3- Kolay ulaşılabilir örnekleme ( )

7- Evrenin Tamamı ( )

4- Küme Örnekleme ( )

8-Belirtilmeyen ( )

\section{6- Örneklem/Çalışma Grubu Büyüklüğü}
1) $0-20 \quad$ ( )
5) $81-100 \quad($ )
9) $301-600 \quad($ )
2) $21-40 \quad($ )
6) $101-150$ ( )
10) $601-1000$ ( )
3) $41-60$
7) $151-200 \quad($ )
11) 1001 ve üzeri ( )
4) $61-80 \quad($ )
8) $201-300 \quad($ )

7- Veri Toplama Araçları

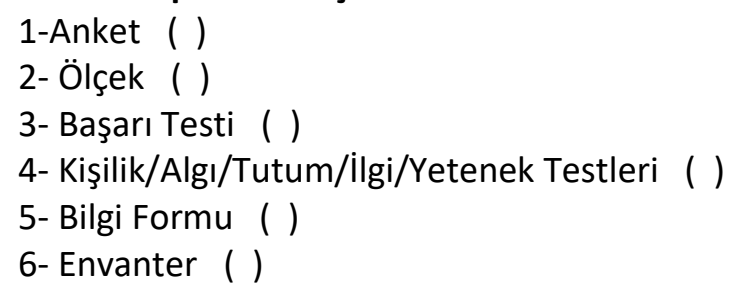

8- Veri Analiz Yöntemi

1- Betimsel İstatistikler (Frekans, yüzde, aritmetik ortalama, standart sapma, mod, ortanca, çarpıklık katsayısı) ( )

2- Kestirisel İstatistikler

a- Parametrik Testler (Anova, t testi, pearson korelasyon, regresyon, manova, ancova) ( )

b- Nonparametrik Testler (Ki-kare,mann-whitney u, spearman korelasyon, friedman, kruskal wallis) ( )

\section{9- Hedef Kitle}

1- Yabancı dil olarak Türkçe öğrenenler ( )

2-Ortaokul öğrencileri ( )

3- Yurt dışındaki Türk öğrenciler ( )

4- Balkan coğrafyasında yaşayan Türk gençleri ( )

6- Öğretmenler ( )

7- Orta öğretim öğrencileri ( )

8- Illkokul öğrencileri ( )

5- Öğretmen adayları ( )

9-Türk soylu öğrenciler ( ) 